\title{
Distribution and geochemical significance of phenylphenanthrenes and their isomers in selected oils and rock extracts from the Tarim Basin, NW China
}

\author{
Shao-Ying Huang ${ }^{1} \cdot$ Mei-Jun $\mathrm{Li}^{2} \cdot \mathrm{Ke}$ Zhang' ${ }^{1}$ T.-G. Wang ${ }^{2} \cdot$ \\ Zhong-Yao Xiaoo ${ }^{1}$ Rong-Hui Fang ${ }^{2} \cdot$ Bao-Shou Zhang ${ }^{1}$ • \\ Dao-Wei Wang ${ }^{2} \cdot$ Qing Zhao $^{1} \cdot$ Fu-Lin Yang ${ }^{2}$
}

Received: 25 July 2015/Published online: 20 April 2016

(c) The Author(s) 2016. This article is published with open access at Springerlink.com

\begin{abstract}
Twenty-two oil samples and eight source rock samples collected from the Tarim Basin, NW China were geochemically analyzed to investigate the occurrence and distribution of phenylphenanthrene (PhP), phenylanthracene $(\mathrm{PhA})$, and binaphthyl (BiN) isomers and methylphenanthrene (MP) isomers in oils and rock extracts with different depositional environments. Phenylphenanthrenes are present in significant abundance in Mesozoic lacustrine mudstones and related oils. The relative concentrations of PhPs are quite low or below detection limit by routine gas chromatography-mass spectrometry (GC-MS) in Ordovician oils derived from marine carbonates. The ratio of 3-PhP/3-MP was used in this study to describe the relative abundance of phenylphenanthrenes to their alkylated counterparts-methylphenanthrenes. The Ordovician oils in the Tabei Uplift have quite low 3-PhP/3-MP ratios $(<0.10)$, indicating their marine carbonate origin, associating with low $\mathrm{Pr} / \mathrm{Ph}$ ratios (pristane/phytane), high ADBT/ ADBF values (relative abundance of alkylated dibenzothiophenes to alkylated dibenzofurans), low $\mathrm{C}_{30}$ diahopane/ $\mathrm{C}_{30}$ hopane ratios, and low Ts/(Ts $+\mathrm{Tm})(18 \alpha-22,29,30$-trisnorneohopane/(18 $\alpha-22,29,30$-trisnorneohopane $+17 \alpha-22$, 29, 30-trisnorhopane)) values. In contrast, the oils from Mesozoic and Paleogene sandstone reservoirs and related Mesozoic lacustrine mudstones have relatively higher 3-PhP/
\end{abstract}

Mei-Jun Li

meijunli2008@hotmail.com

1 Research Institute of Petroleum Exploration and Development, Tarim Oilfield Company, PetroChina, Korla 841000, Xinjiang, China

2 State Key Laboratory of Petroleum Resources and Prospecting, College of Geosciences, China University of Petroleum, Beijing 102249, China

Edited by Jie Hao
3-MP ratios ( $>0.10)$, associating with high $\mathrm{Pr} / \mathrm{Ph}$, low ADBT/ $\mathrm{ADBF}$, high $\mathrm{Ts} /(\mathrm{Ts}+\mathrm{Tm})$, and $\mathrm{C}_{30}$ diahopane/ $\mathrm{C}_{30}$ hopane ratios. Therefore, the occurrence of significant amounts of phenylphenanthrenes in oils typically indicates that the organic matter of the source rocks was deposited in a suboxic environment with mudstone deposition. The phenylphenanthrenes may be effective molecular markers, indicating depositional environment and lithology of source rocks.

Keywords Phenylphenanthrene - Methylphenanthrene · Depositional environment $\cdot$ Source rock

\section{Introduction}

Phenyl-substituted polycyclic aromatic hydrocarbons (PAHs) and their heterocyclic counterparts are important components in aromatic fractions of some crude oils and sedimentary rock extracts (Marynowski et al. 2001, 2002, 2004; Rospondek et al. 2007, 2009; Li et al. 2012a; Grafka et al. 2015). A series of phenylphenanthrene (PhP), phenylanthracene $(\mathrm{PhA})$, and binaphthyl $(\mathrm{BiN})$ isomers have been firmly identified by using authentic standards (Rospondek et al. 2009).

The 9-phenylphenanthrene and other isomers were detected in volatiles formed during pyrolytic carbonization of coal tar pitches (zu Reckendorf 1997, 2000). All PhP, $\mathrm{PhA}$, and $\mathrm{BiN}$ isomers have been discovered in marine sedimentary rocks (Rospondek et al. 2009; Grafka et al. 2015), Tertiary and Jurassic lacustrine shales ( $\mathrm{Li}$ et al. 2012a) and tire fire products (Wang et al. 2007).

The phenyl-substituted PAHs in combustion products may be generated by consecutive reactions of phenyl free radicals with unsubstituted PAHs in the gaseous phase during combustion (zu Reckendorf 2000). Less work has 
been done on the origin and formation of phenylphenanthrene in crude oils and sedimentary rocks. According to Marynowski et al. (2001), Rospondek et al. (2009), and Grafka et al. (2015), diagenetic/catagenetic oxidation of sedimentary organic matter at the redox interface in buried sedimentary rocks is likely to be the main source of arylated polycyclic aromatic compounds in the geosphere. Laboratory experiments indicate that the reaction of free radical phenylation with phenanthrene or anthracene moieties can account for the distribution of phenylphenanthrenes and phenylanthracenes in oxidized rock samples with Type II and III kerogen (Marynowski et al. 2001; Rospondek et al. 2009; Grafka et al. 2015). Therefore, a significant amount of PhPs and other phenyl-substituted PAHs in ancient sedimentary rocks are commonly associated with oxic to suboxic depositional environments.

The distribution patterns of PhPs and BiNs in mass chromatograms $(\mathrm{m} / \mathrm{z}, 254)$ of aromatic fractions in sedimentary organic matters are relative to the maturation levels. For example, the most stable isomers 2-PhP and $3-\mathrm{PhP}$ predominate, whereas the thermally unstable $9-\mathrm{PhP}$, 1-PhP, and 4-PhP disappear in highly mature sedimentary organic matter (Rospondek et al. 2009; Li et al. 2012a; Grafka et al. 2015). Among all binaphthyl isomers, 1,1-BiN is the most thermally unstable one and was found only in less mature samples; while 2,2-BiN is more stable and also present above the oil window range (Rospondek et al. 2009; Li et al. 2012a). Therefore, some indices, such as phenylphenanthrene ratio [defined as $(2-+3-\mathrm{PhP}) /(2-$ $+3-+4-+1-+9-\mathrm{PhP})$ ] (Rospondek et al. 2009) and 2,2'-BiN/1,2'-BiN (defined as 2,2'-binaphthyl/1,2'-binaphthyl) (Li et al. 2012a) have been proposed as maturity indicators. In addition, some maturity indicators associated with aromatic compounds including phenylphenanthrene ratios have also been used as frictional stress indicators (Polissar et al. 2011).

Previous studies mainly focused on the formation and application of PhPs in maturation assessment. This paper reported the occurrence of $\mathrm{PhPs}$ in Ordovician oils, Mesozoic lacustrine sedimentary rocks, and related oils from the Tarim Basin, NW China. Their potential significance to the depositional environment and lithology of source rocks and application in oil-to-source correlation in oil petroleum system are discussed. The result can further broaden the geochemical significance and application of phenylphenanthrenes in sedimentary rocks and related oils.

\section{Samples and geological settings}

A total of eight cores and outcrop samples were collected from the Tarim Basin, NW China. Two cores were sampled from Well S5, which is located in the Yakela Faulted Uplift
(Fig. 1). One outcrop was sampled in the Kuchehe profile in the Kuqa Depression, which is the prolific hydrocarbonbearing foreland basin in the Tarim Basin (Zhao et al. 2005). These three rock samples are Upper Triassic mudstones.

Four Jurassic sandy mudstones were collected from the Kuzigongsu profile in the southwest of the Tarim Basin (Fig. 1). The Middle Jurassic in the Tarim Basin is represented by deep lacustrine deposits (Zhang et al. 2000; Liu et al. 2006; Cheng et al. 2008; Wang et al. 2009; Song et al. 2013). In addition, one Jurassic coal sample from the Well YL1 in the eastern Tarim Basin is also investigated. All these samples are good source rocks with total organic carbon (TOC) content of $0.71 \%-1.12 \%$ (Table 1), and they underwent moderate to relatively higher thermal maturation with vitrinite reflectance $\left(R_{\mathrm{O}} \%\right)$ of $0.51 \%$ $1.10 \%$ (Table 1 ).

A total of 22 oil samples were collected from the Ordovician carbonate reservoirs in the Halahatang Sag, Yakela Faulted Uplift and Akekule Uplift, and the Mesozoic and Paleogene sandstone reservoirs in the Kuqa Depression and Yakela Uplift of the Tarim Basin (Table 1). The Ordovician carbonate oils from the Tabei Uplift were sourced from Paleozoic carbonate source rocks (Zhang and Huang 2005; Wang et al. 2008; Pang et al. 2010; Li et al. 2012b). Oils in wells QL1, Ku1, and S3 were derived from Mesozoic lacustrine mudstones (Xiao et al. 2004; Song et al. 2015).

\section{Methods}

All rocks were ground into powder in a crusher to $<80$ mesh. The TOC content was measured on an LECO CS230 carbon/sulfur analyzer. The vitrinite reflectance values (\%) were measured on polished rock blocks using a Leitz MPV-microscopic photometer.

To extract soluble bitumen, the powder was processed for $24 \mathrm{~h}$ in a Soxhlet apparatus using $400 \mathrm{~mL}$ of dichloromethane and methanol as the solvent (93:7, v:v). Asphaltenes were removed from approximately $20-50 \mathrm{mg}$ oils and bitumen by precipitation using $50 \mathrm{~mL}$ of $n$-hexane and then fractionated by liquid chromatography using alumina/silica gel columns into saturated and aromatic hydrocarbons using $30 \mathrm{~mL} n$-hexane and $20 \mathrm{~mL}$ dichloromethane: $n$-hexane (2:1, v:v) as respective eluents (Fang et al. 2015).

The GC-MS analyses of the aromatic fractions were performed on an Agilent 5975i GC-MS system equipped with an HP-5MS (5\%-phenylmethylpolysiloxane)-fused silica capillary column $(60 \mathrm{~m} \times 0.25 \mathrm{~mm}$ i.d., with a 0.25 $\mu \mathrm{m}$ film thickness). The GC operating conditions were as follows: the temperature was held initially at $80{ }^{\circ} \mathrm{C}$ for 


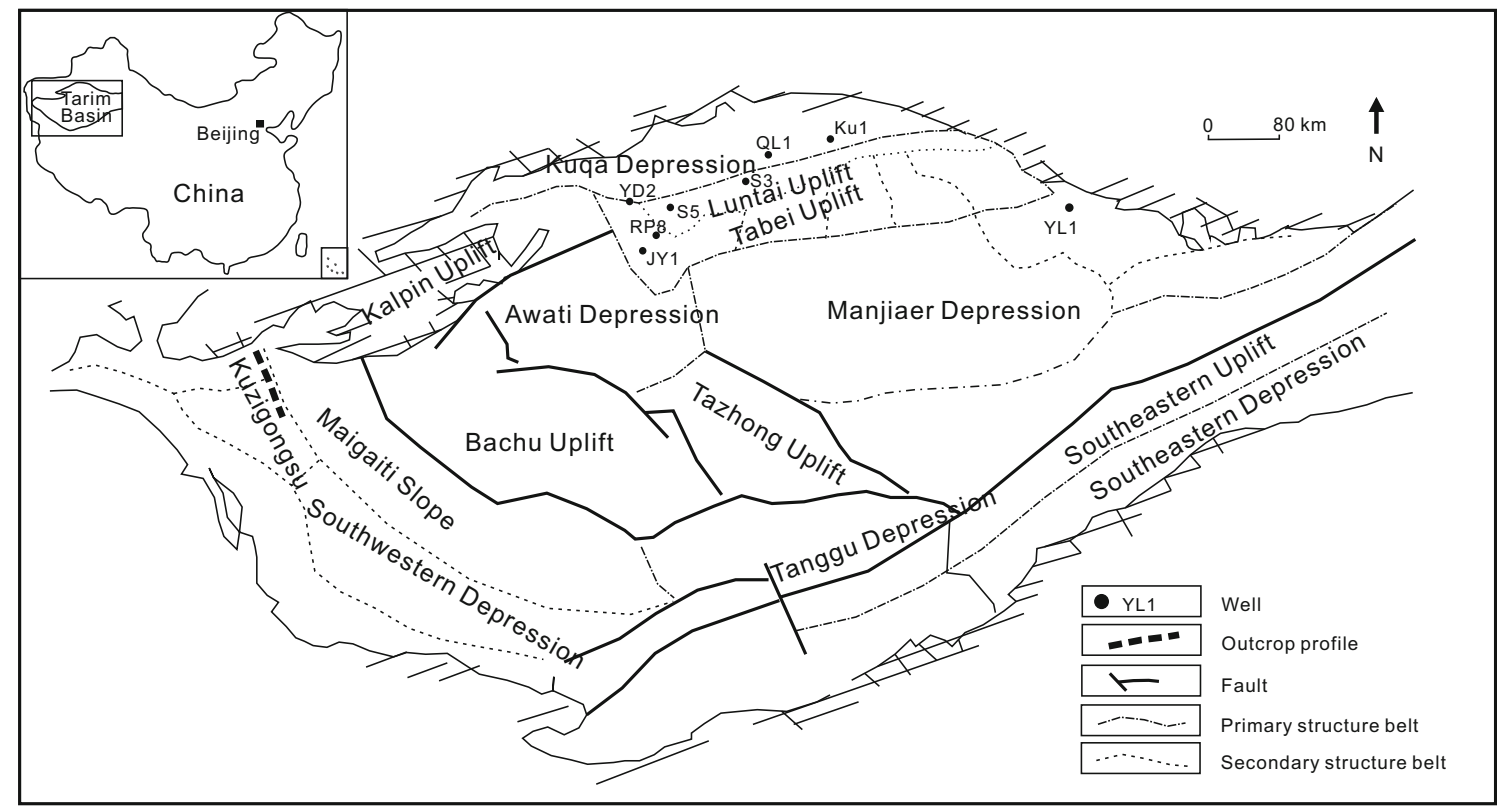

Fig. 1 Map showing the major tectonic terrains in the Tarim Basin (NW China) and the locations of sampled wells and profiles

$1 \mathrm{~min}$, increased to $310{ }^{\circ} \mathrm{C}$ at a rate of $3{ }^{\circ} \mathrm{C} / \mathrm{min}$, and then kept isothermal for $16 \mathrm{~min}$. Helium was used as the carrier gas. The injector temperature was set to $300{ }^{\circ} \mathrm{C}$. The MS was operated in the electron impact (EI) mode with ionization energy of $70 \mathrm{eV}$, and a scan range of $m / z 50-600 \mathrm{Da}$.

\section{Results and discussion}

\subsection{Identification of phenylphenanthrenes and methylphenanthrenes}

The identification and elution order of all isomers of methylphenanthrenes (MPs), phenylphenanthrenes (including their isomers: phenylanthracene and binaphthyl) were determined by the comparison of their mass spectra and standard retention indices $\left(I_{\mathrm{HP}-5 \mathrm{MS}}\right)$ with those reported in literature (Lee et al. 1979; Rospondek et al. 2009). Figure 2 shows the chemical structures of MPs and PhPs and the mass chromatograms $(\mathrm{m} / \mathrm{z}, 178,192,254)$ of aromatic fractions of selected sediment extracts in this study. The methyl and phenyl substitution pattern on parent rings is indicated on the corresponding peaks (Fig. 2).

Phenanthrene and its alkylated homologues are important polycyclic aromatic hydrocarbons (PAHs) and present in significant concentrations in crude oils and sedimentary rock extracts. Four methylphenanthrene isomers and one methylanthracene isomer (2-methylanthracene: 2-MA) were identified in all rocks and oils in this study. The elution order of the $\mathrm{m} / \mathrm{z} 192$ isomers is as follows: 3-MP, 2-MP, 2-MA, 9-MP, and 1-MP. The isomer 2-MA is present in quite low concentration or below detection limit in oils (Figs. 3, 4). However, it seems abundant in some rocks and coals (Figs. 2c, 4a, b e).

The distribution of arylated homologues of phenanthrenes (phenylphenanthrenes) is shown in Fig. 2. In addition, their binaphthyl (BiN) isomers were also detected in oils and rock extracts. The elution sequence of $m / z 254$ isomers on an HP-5MS capillary column is as follows: $1,1^{\prime}$ BiN, 4-PhP, 9-PhA, 1,2'-BiN, 9-PhP, 1-PhP, 3-PhP, 2,2'$\mathrm{BiN}, 2-\mathrm{PhP}$, and 2-PhA. The 1-PhA isomer may co-elute with $1,2^{\prime}$-BiN on HP-5MS column, but it is typically absent in geochemical samples (Rospondek et al. 2009). The isomers 3-PhP, 2-PhP, and 2,2'-BiN are typically present in higher abundance relative to other $\mathrm{PhP}$ and $\mathrm{BiN}$ isomers.

\subsection{Depositional environment and lithologies of crude oils and source rocks}

Previous studies suggested that oils in wells Ku1 and QL1 of the Kuqa Depression and wells YD2 and S3 of the Tabei Uplift (Fig. 1) are of typical lacustrine mudstone origin ( $\mathrm{Li}$ et al. 2004; Xiao et al. 2004; Song et al. 2015). Oils from Ordovician carbonate reservoirs were derived from Paleozoic carbonate source rocks (Zhang and Huang 2005; Wang et al. 2008; Chang et al. 2013).

Dibenzothiophene, dibenzofuran, and their alkylated homologues are effective molecular markers in inferring depositional environment, maturation assessment and in tracing oil charging pathways (Bao et al. 1996; Wang et al. 2014; Li et al. 2008; Zhang and Philp. 2010; Li et al. 2011, 2014). A cross-plot of alkyldibenzothiophene/alkyldibenzofuran ratio 
Table 1 Bulk properties and selected geochemical parameters for oils and rocks in this study

\begin{tabular}{|c|c|c|c|c|c|c|c|c|c|c|}
\hline $\begin{array}{l}\text { Sample } \\
\text { no. }\end{array}$ & Fm. & Description & TOC, $\%$ & $R_{\mathrm{o}}, \%$ & $\begin{array}{l}\text { Methylphenanthrene } \\
\text { index (MPI1) }\end{array}$ & $\begin{array}{l}\text { 3- } \mathrm{PhP} / \\
\text { 3-MP }\end{array}$ & $\begin{array}{l}\mathrm{Pr} / \\
\mathrm{Ph}\end{array}$ & $\begin{array}{l}\text { ADBT/ } \\
\text { ADBF }\end{array}$ & $\begin{array}{l}\mathrm{C}_{30} \mathrm{DiaH} / \\
\mathrm{C}_{30} \mathrm{H}\end{array}$ & $\begin{array}{l}\mathrm{Ts} /(\mathrm{Ts}+ \\
\mathrm{Tm})\end{array}$ \\
\hline YD2 & Cretaceous & Oil, Tabei Uplift & - & - & 0.51 & 0.12 & 2.17 & 0.54 & 0.48 & 0.67 \\
\hline S3 & Cretaceous & Oil, Yakela Faulted Uplift & - & - & 1.11 & 0.09 & 1.63 & 0.33 & 0.92 & 0.66 \\
\hline Ku1 & Jurassic & Oil, Kuqa Depression & - & - & 0.13 & 0.17 & 1.84 & 0.26 & 0.50 & 0.55 \\
\hline QL1 & Paleogene & Oil, Kuqa Depression & - & - & 0.66 & 0.60 & 1.79 & 0.48 & 0.64 & 0.63 \\
\hline RP10 & Ordovician & Oil, Halahatang Sag & - & - & 0.78 & 0.03 & 0.81 & 7.52 & 0.09 & 0.37 \\
\hline RP4 & Ordovician & Oil, Halahatang Sag & - & - & 0.38 & 0.01 & 0.76 & 8.06 & 0.08 & 0.42 \\
\hline RP3013 & Ordovician & Oil, Halahatang Sag & - & - & 0.96 & 0.03 & 0.92 & 9.06 & 0.12 & 0.53 \\
\hline RP11 & Ordovician & Oil, Halahatang Sag & - & - & 0.78 & 0.02 & 0.97 & 6.71 & 0.12 & 0.45 \\
\hline RP8 & Ordovician & Oil, Halahatang Sag & - & - & 0.87 & 0.03 & 0.75 & 10.5 & 0.12 & 0.45 \\
\hline JY1 & Ordovician & Oil, Halahatang Sag & - & - & 0.96 & 0.02 & 0.83 & 7.16 & 0.12 & 0.58 \\
\hline JY7 & Ordovician & Oil, Halahatang Sag & - & - & 0.92 & 0.02 & 1.04 & 9.06 & 0.09 & 0.49 \\
\hline JY3 & Ordovician & Oil, Halahatang Sag & - & - & 0.70 & 0.02 & 1.03 & 8.61 & 0.09 & 0.45 \\
\hline XK5 & Ordovician & Oil, Halahatang Sag & - & - & 0.85 & 0.02 & 0.82 & 6.81 & 0.10 & 0.42 \\
\hline XK4 & Ordovician & Oil, Halahatang Sag & - & - & 0.71 & 0.01 & 0.97 & 5.39 & 0.08 & 0.40 \\
\hline XK7 & Ordovician & Oil, Halahatang Sag & - & - & 0.79 & 0.03 & 0.81 & 7.69 & 0.09 & 0.29 \\
\hline XK9005 & Ordovician & Oil, Halahatang Sag & - & - & 0.94 & 0.01 & 1.05 & 9.83 & 0.08 & 0.46 \\
\hline Ha601 & Ordovician & Oil, Halahatang Sag & - & - & 0.72 & 0.02 & 0.88 & 5.63 & 0.17 & 0.44 \\
\hline $\mathrm{Ha} 7-1$ & Ordovician & Oil, Halahatang Sag & - & - & 0.80 & 0.01 & 1.00 & 9.08 & 0.17 & 0.43 \\
\hline $\mathrm{Ha} 8$ & Ordovician & Oil, Halahatang Sag & - & - & 0.70 & 0.02 & 0.98 & 6.52 & 0.12 & 0.37 \\
\hline Ha13-6 & Ordovician & Oil, Halahatang Sag & - & - & 0.74 & 0.01 & 1.01 & 6.84 & 0.11 & 0.46 \\
\hline TP12-8 & Ordovician & Oil, Akekule & - & - & 0.89 & 0.03 & 0.91 & 2.72 & 0.08 & 0.49 \\
\hline TP14 & Ordovician & Oil, Akekule & - & - & 0.65 & 0.02 & 0.87 & 10.10 & 0.06 & 0.45 \\
\hline S5 & Triassic & Mudstone, core, $5400.8 \mathrm{~m}$ & 0.71 & 0.74 & 0.48 & 0.11 & 1.26 & 0.17 & 0.65 & 0.85 \\
\hline S5 & Triassic & Mudstone, core, $5405.4 \mathrm{~m}$ & 0.73 & 0.75 & 0.42 & 0.10 & 1.21 & 0.75 & n.d. & 0.87 \\
\hline Ku-13 & Jurassic & $\begin{array}{l}\text { Sandy mudstone, outcrop, } \\
\text { Kuzigongsu }\end{array}$ & 1.64 & 1.10 & 0.72 & 0.17 & 1.56 & 0.47 & 1.55 & 0.76 \\
\hline $\mathrm{Ku}-18$ & Jurassic & $\begin{array}{l}\text { Sandy mudstone, outcrop, } \\
\text { Kuzigongsu }\end{array}$ & 2.02 & 0.99 & 0.64 & 0.16 & 2.10 & 0.22 & 2.97 & 0.86 \\
\hline $\mathrm{Ku}-26$ & Jurassic & $\begin{array}{l}\text { Sandy mudstone, outcrop, } \\
\text { Kuzigongsu }\end{array}$ & 3.53 & 0.94 & 0.19 & 0.98 & 1.59 & 0.12 & 6.71 & 0.96 \\
\hline $\mathrm{Ku}-30$ & Jurassic & $\begin{array}{l}\text { Sandy mudstone, outcrop, } \\
\text { Kuzigongsu }\end{array}$ & 3.27 & 0.93 & 0.22 & 0.90 & 2.00 & 0.10 & 4.48 & 0.92 \\
\hline YL1 & Jurassic & Coal, core, $2878.0 \mathrm{~m}$ & 38.4 & 0.51 & 0.35 & 0.33 & 3.77 & 0.50 & n.d. & n.d. \\
\hline $\mathrm{KCH}-01$ & Triassic & $\begin{array}{l}\text { Mudstone, outcrop, } \\
\text { Kuchehe }\end{array}$ & 1.12 & & 0.26 & 1.44 & 2.08 & 0.31 & n.d. & 0.88 \\
\hline
\end{tabular}

n.d.: no data

(ADBT/ADBF) versus pristane/phytane ratio $(\mathrm{Pr} / \mathrm{Ph})$ provides a powerful and convenient way to infer crude oil source rock depositional environments and lithologies (Radke et al. 2000). The oils from Ordovician reservoirs in the Tabei Uplift were characterized by lower $\mathrm{Pr} / \mathrm{Ph}$ ratio and higher ADBT/ADBF ratio (Table 1), and the data points were plotted in Zone $1 \mathrm{~A}$ of the cross-plot of ADBT/ADBF versus $\mathrm{Pr} / \mathrm{Ph}$ ratios, indicating their marine carbonate origin (Fig. 5).

Oils from Jurassic and Paleogene reservoirs in the Kuqa Depression and oils from Cretaceous reservoirs in the Tabei Uplift have relatively higher $\mathrm{Pr} / \mathrm{Ph}$ values and very low ADBT/ADBF values. All these data points fall into
Zone 3 (Fig. 5), suggesting the mudstone lithology of their source rocks. On the basis of oil-to-source correlation results, all these oils were derived from Mesozoic lacustrine mudstone source rocks (e.g., Song et al. 2015).

Selected Mesozoic mudstones from the Kuqa Depression and the Tabei Uplift were also analyzed. All rock samples have relatively higher $\mathrm{Pr} / \mathrm{Ph}$ ratios and quite low values of ADBT/ADBF. The points also fall into Zone 3, indicating their lacustrine mudstone lithology (Fig. 5). The coal sample from Well YL1 in the eastern Tarim Basin has very high $\mathrm{Pr} / \mathrm{Ph}$ ratio, which falls into Zone 4 (fluvial/ deltaic carbonaceous shale and coal zone). 

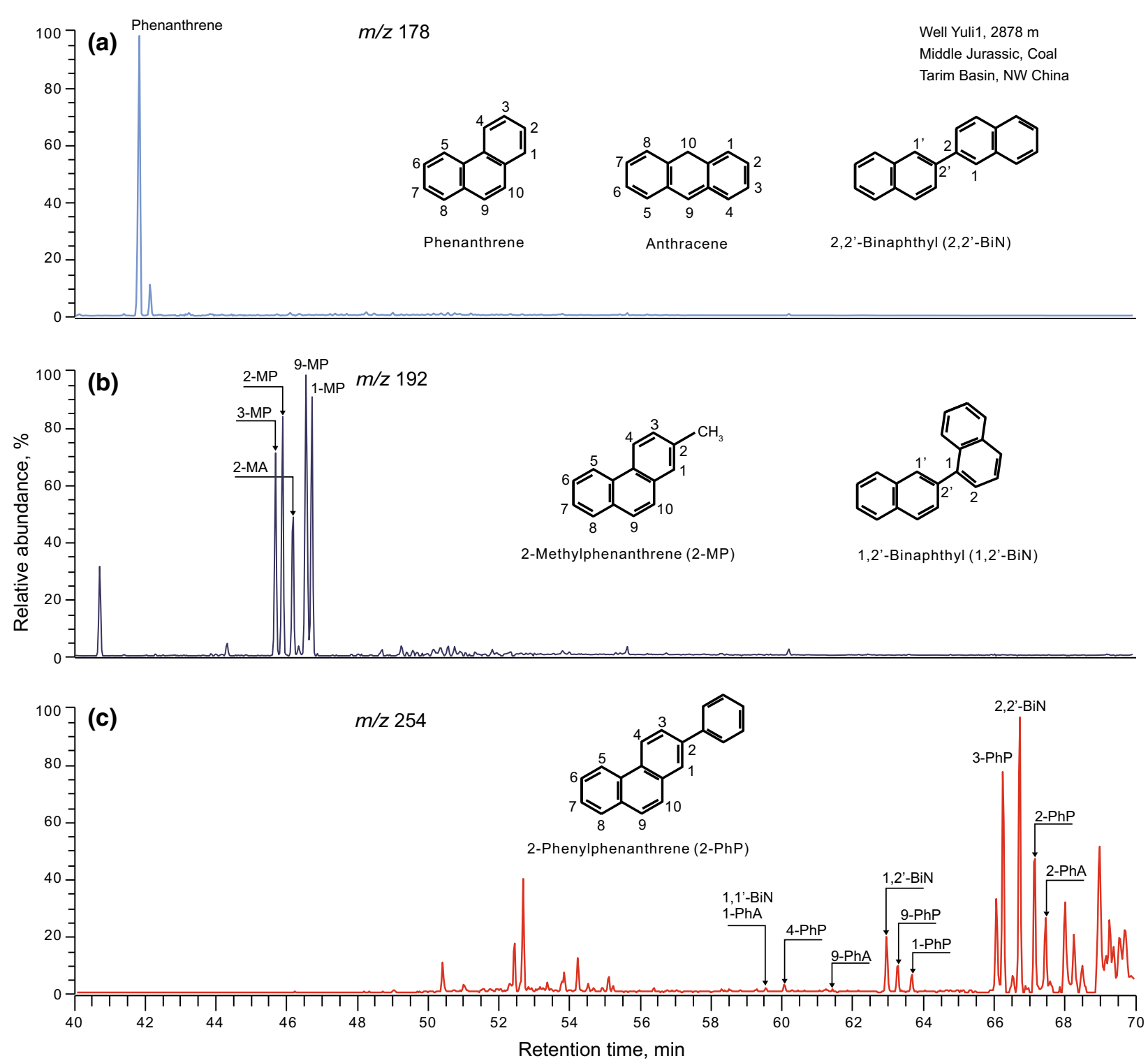

Fig. 2 Identification of phenanthrene $(\mathrm{m} / \mathrm{z}, 178)$, methylphenanthrene and methylanthracene $(\mathrm{m} / \mathrm{z}, 192)$, and phenylphenanthrene, phenylanthracene, and binaphthyl isomers $(\mathrm{m} / \mathrm{z}, 254)$ in sedimentary rocks and their chemical structures

Therefore, the relative abundances of alkylated dibenzothiophenes to alkylated dibenzofurans and pristane to phytane confirm that the oils in the Ordovician reservoirs are of marine carbonate origin and the oils from Mesozoic and Paleogene sandstone reservoirs in the Kuqa Depression and Tabei Uplift of the Tarim Basin are of lacustrine mudstone origin.

\subsection{Distribution of PhPs and MPs in oils and source rocks}

Most of the phenylphenanthrene isomers were detected in oils from wells Ku1, QL1, YD2, and S3 (Fig. 3a-d). They are present in differing abundance in these oils. The isomer of $2,2^{\prime}$-biphenyl is typically present in quite low concentrations, and 1,2'-biphenyl is commonly absent or under detection limit. The 3-PhP is the dominant compound among all $\mathrm{PhP}, \mathrm{PhA}$, and $\mathrm{BiN}$ isomers in $m / z, 254$ mass chromatograms. The concentrations of $\mathrm{PhPs}$ are generally lower than those of their methylated counterparts-MPs in all oils. Here we defined 3-PhP/3-MP to indicate the relative abundance of PhPs to MPs. The oils from wells $\mathrm{Ku} 1$, QL1, YD2, and S3 have 3-PhP/3-MP ratios higher than 0.10 . However, oils from Ordovician reservoirs in the Tabei Uplift, including Ha6, Repu, Xinken, Jinyue, and Tuofutai blocks, have extremely low concentrations of phenylphenanthrenes with 3-PhP/3-MP ratios lower than 0.10 (Fig. 4e, f; Table 1).

Selected Mesozoic lacustrine mudstones were also investigated to analyze the distribution patterns of $\mathrm{PhPs}$ and 

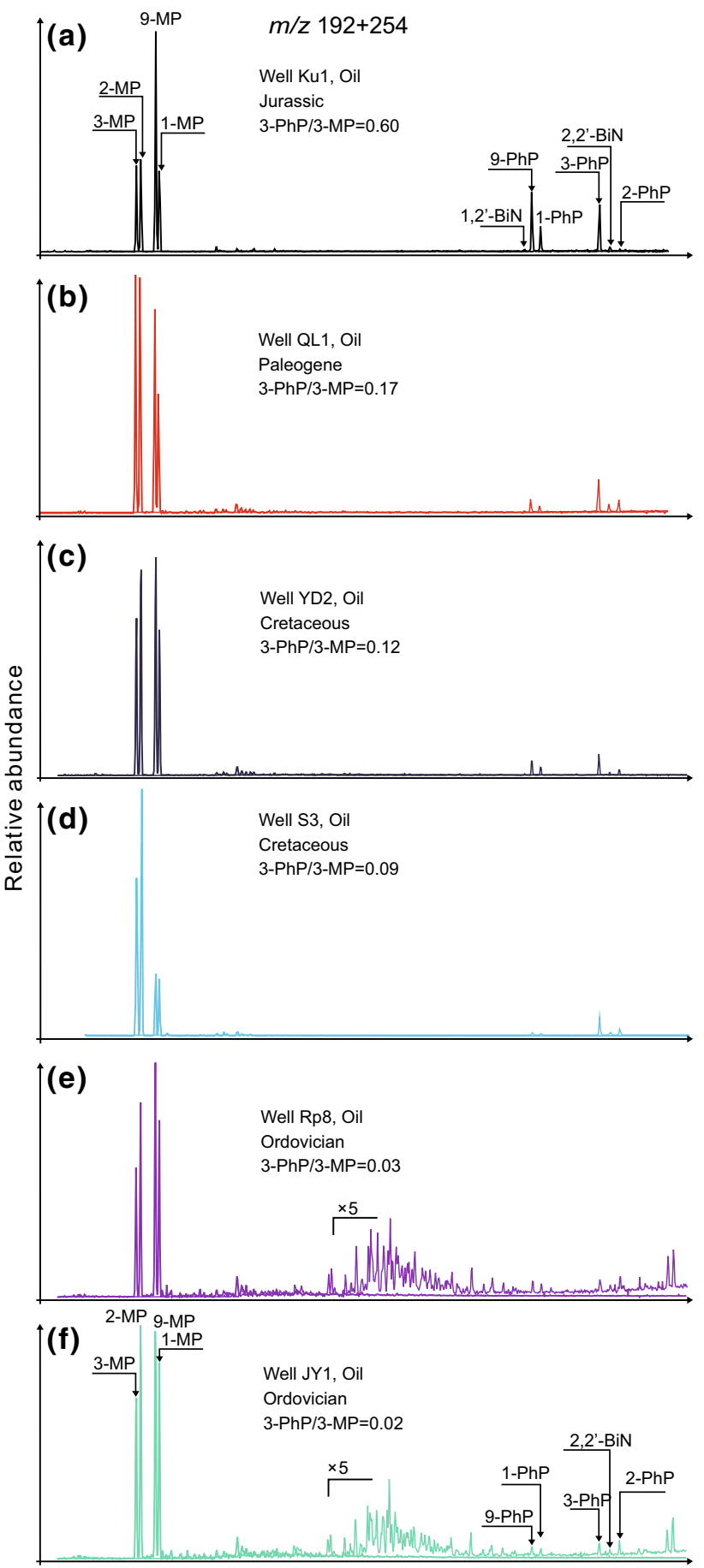

Relative retention time

Fig. 3 Distribution of methylphenanthrenes $(\mathrm{m} / \mathrm{z}$ 192), phenylphenanthrenes $(\mathrm{m} / z, 254)$, and their isomers in selected oils from the Tarim Basin

MPs in sedimentary rock extracts. Most of the PhP isomers and 2,2'-BiN were detected in all rocks in this study. For the lower thermodynamic stability, $\mathrm{PhAs}$ and $1,1^{\prime}$-BiN are generally below detection limit in this study. The ratio of 3- $\mathrm{PhP} / 3-\mathrm{MP}$ in Mesozoic lacustrine mudstones is from 0.11 to 1.44 , which is consistent with oils from wells Ku1, QL1,
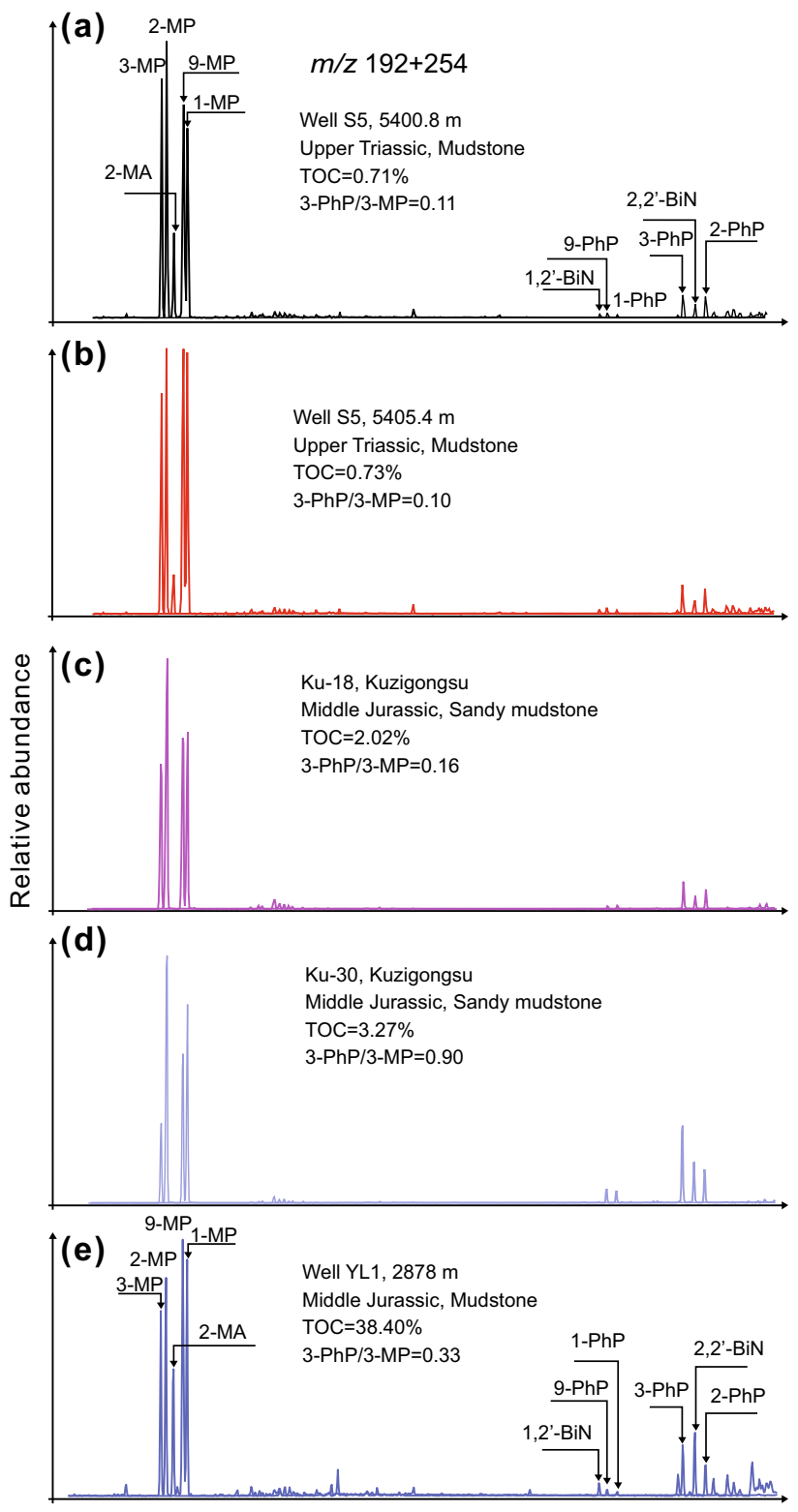

Relative retention time

Fig. 4 Distribution of methylphenanthrenes $(\mathrm{m} / \mathrm{z} \quad 192)$, phenylphenanthrenes $(\mathrm{m} / \mathrm{z}, 254)$, and their isomers in Mesozoic source rocks in the Tarim Basin

YD2, and S3. Therefore, the occurrence and distribution of phenylphenanthrene and methylphenanthrenes in Mesozoic oils and source rocks further confirmed their genetic affinity.

\subsection{Effect of environment and lithology on the distribution of MPs and PhPs}

Much work has been done on the occurrence and distribution of methylated phenanthrenes. For example, Alexander et al. (1995) demonstrated that the sedimentary methylation process can form some alkylphenanthrene isomers. Due to the ubiquitous occurrence, the methylphenanthrenes appear to 


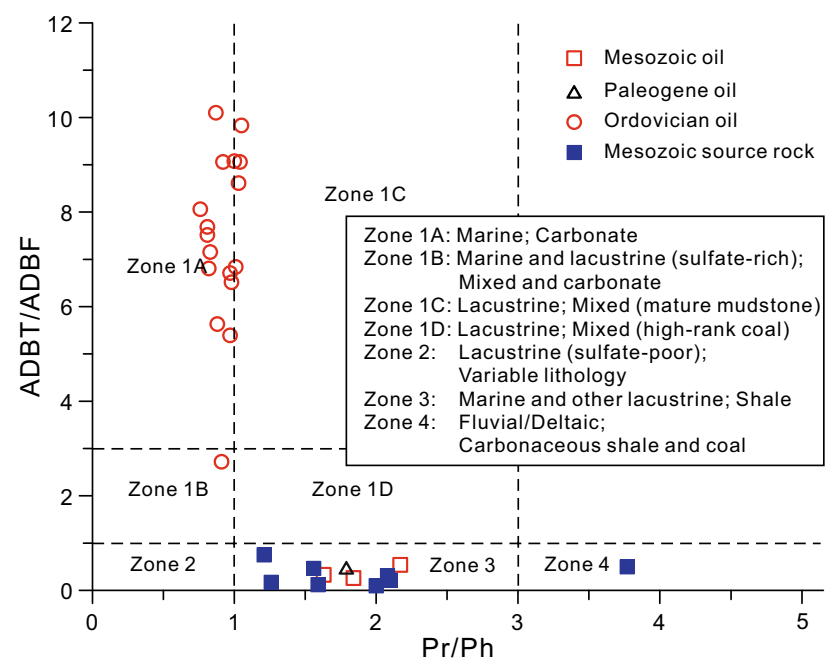

Fig. 5 Cross-plot of alkyldibenzothiophene/alkyldibenzofuran ratio (ADBT/ADBF) versus pristane/phytane ratio $(\mathrm{Pr} / \mathrm{Ph})$ showing crude oil source rock depositional environments and lithologies (after Radke et al. 2000)

have limited depositional environment and lithology significance. They are effective molecular markers for thermal maturity assessment (e.g., Radke et al. 1982; Boreham et al. 1988; Voigtmann et al. 1994; Szczerba and Rospondek 2010).

Here we use 3-PhP/3-MP to show the abundance of phenylphenanthrenes relative to methylphenanthrenes in oils and sedimentary organic matter. The abundance of parent phenanthrene may be different for the differences in the input of organic matter in source rocks and/or thermal maturation level of sedimentary organic matter. As proposed by previous studies (Marynowski et al. 2001; Rospondek et al. 2009), the phenylation of phenanthrene is mainly associated with an oxidizing depositional environment. Therefore, an oxic to suboxic environment may favor the formation of phenylphenanthrenes. The cross-plot of $\mathrm{Ts} /(\mathrm{Ts}+\mathrm{Tm})$ versus 3-PhP/3-MP is used here to investigate the effect of the depositional environment and lithology on the distribution patterns of MPs and PhPs. The Ts/ $(\mathrm{Ts}+\mathrm{Tm}) \quad$ ratio $(18 \alpha-22,29,30$-trisnorneohopane/(18 $\alpha$ 22,29,30-trisnorneohopane $+17 \alpha-22,29,30$-tris-

norhopane)) depends on both source and maturity (Moldowan et al. 1986). It is a reliable maturity indictor when assessing oils from a common source of consistent organic facies (Peters et al. 2005). This ratio increases with the increasing maturity. It is sensitive to clay-catalyzed reactions. For example, oils from carbonate source rocks appear to have low $\mathrm{Ts} /(\mathrm{Ts}+\mathrm{Tm})$ ratios compared with those from shales (e.g., Rullkötter et al. 1985).

Here we found that oils from Ordovician reservoirs have relatively lower $\mathrm{Ts} /(\mathrm{Ts}+\mathrm{Tm})$ values $(<0.50)$ and very low 3-PhP/3-MP ratios $(<0.10)$. In contrast, the Mesozoic and Paleogene oils from wells Ku1, QL1, S3, and YD2 and Mesozoic lacustrine mudstones have higher $\mathrm{Ts} /(\mathrm{Ts}+\mathrm{Tm})$

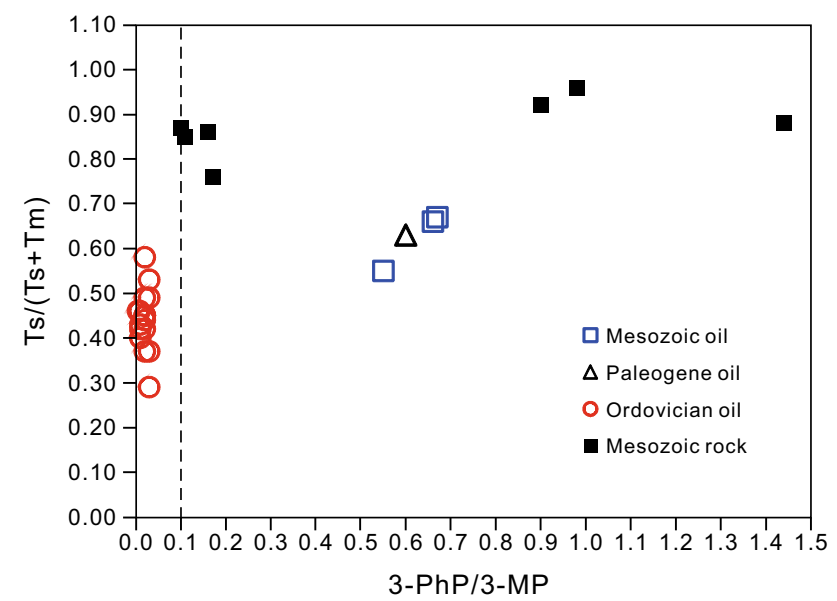

Fig. 6 The cross-plot of $\mathrm{Ts} /(\mathrm{Ts}+\mathrm{Tm})$ versus $3-\mathrm{PhP} / 3-\mathrm{MP}$ ratio provides a useful way to infer the depositional environment and lithology of oils and related source rocks. Ts $-\mathrm{C}_{27} \quad 18 \alpha-22,29,30-$ trisnorneohopane; $\mathrm{Tm}-\mathrm{C}_{27} 17 \alpha$-22,29,30-trisnorhopane

$(>0.55)$ and 3-PhP/3-MP ratios $(>0.10)$ (Fig. 6). The higher Ts/(Ts $+\mathrm{Tm})$ ratios for Mesozoic oils and source rocks are mainly attributed to a suboxic depositional environment and clay-rich lithology, because Ordovician oils sourced from Paleozoic marine source rocks have generally higher maturation levels than those from the Mesozoic lacustrine source rocks.

The $\mathrm{C}_{30}$ diahopane in sedimentary rock extracts and oils may be derived from bacterial hopanoid precursors that have experienced oxidation and rearrangement by claymediated acidic catalysis. Therefore, the presence of a significant amount of $\mathrm{C}_{30}$ diahopane indicates bacterial input to sediments containing clays deposited under oxic or suboxic environments (Peters et al. 2005). In this study, the $\mathrm{C}_{30}$ diahopane is generally present in very low concentration in Ordovician oils (with $\mathrm{C}_{30}$ diahopane/ $\mathrm{C}_{30}$ hopane ratios lower than 0.20). While Mesozoic and Paleogene oils from wells Ku1, QL1, S3, and YD2 and Mesozoic lacustrine mudstones have higher $\mathrm{C}_{30}$ diahopane/ $\mathrm{C}_{30}$ hopane ratios (Table 1). Therefore, our study suggests that the presence of a significant amount of phenylphenanthrenes is generally related to clay-enriched sediments deposited under suboxic conditions.

\section{Conclusions}

Phenyl phenanthrenes and their isomers have been detected in oils and source rocks from the Tarim Basin, NW China. 3-phenylphenanthrene (3-PhP), 2-PhP, and 1,2'-binaphthyls $\left(1,2^{\prime}-\mathrm{BiN}\right)$ are typically predominant compounds among all isomers. The abundances of phenylphenanthrenes are extremely low in Ordovician oils in the Tabei Uplift of the Tarim Basin. The Mesozoic oils from wells QL1 and 
Ku1 from the Kuqa Depression and wells S3 and YD2 from the Tabei Uplift have relatively higher concentrations of phenylphenanthrenes.

The ratio of 3-PhP/3-MP (3-phenylphenanthrene/3methylphenanthrene) is used to indicate the relative abundances of phenylphenanthrenes to methylphenanthrenes. We discovered that oils from marine carbonate source rocks have a very low ratio $(<0.10)$. However, oils of lacustrine mudstone origin and related source rocks have relatively high 3- $\mathrm{PhP} / 3-\mathrm{MP}$ ratios, associating with higher $\mathrm{Pr} / \mathrm{Ph}, \mathrm{Ts} /$ $(\mathrm{Ts}+\mathrm{Tm})$ and $\mathrm{C}_{30}$ diahopane/ $\mathrm{C}_{30}$ hopane values.

The occurrence and distribution of phenylphenanthrenes in oils and sedimentary rock extracts in the Tarim Basin clearly show an environment dependence. Relatively higher abundance of phenylphenanthrenes (3-PhP/3-MP higher than 0.10) generally suggests clay-enriched sediments under suboxic depositional environment. Certainly, further work is needed to investigate whether this is valid in other basins.

Acknowledgments The work was financially supported by the National Natural Science Foundation of China (Grant No. 41272158) and the State Key Laboratory of Petroleum Resources and Prospecting (PRP/indep-2-1402). The authors thank the assistance of Zhu Lei in the GC-MS analysis. We are grateful to three anonymous reviewers for their constructive comments and suggestions. We thank the Tarim Oilfield Company of PetroChina for providing samples and data, and for permission to publish this work.

Open Access This article is distributed under the terms of the Creative Commons Attribution 4.0 International License (http://crea tivecommons.org/licenses/by/4.0/), which permits unrestricted use, distribution, and reproduction in any medium, provided you give appropriate credit to the original author(s) and the source, provide a link to the Creative Commons license, and indicate if changes were made.

\section{References}

Alexander R, Bastow TP, Fisher SJ, et al. Geosynthesis of organic compounds: II. Methylation of phenanthrene and alkylphenanthrenes. Geochim Cosmochim Acta. 1995;59(20):4259-66.

Bao JP, Wang TG, Chen FJ. Relative abundance of alkyl dibenzothiophenes in the source rocks and their geochemical significances. J China Univ Pet. 1996;20:19-23 (in Chinese).

Boreham CJ, Crick IH, Powell TG. Alternative calibration of the Methylphenanthrene index against vitrinite reflectance: application to maturity measurements on soils and sediments. Org Geochem. 1988;12:289-94.

Chang X, Wang T-G, Li Q, et al. Geochemistry and possible origin of petroleum in Palaeozoic reservoirs from Halahatang Depression. J Asian Earth Sci. 2013;74:129-41.

Cheng X, Liao L, Chen X, et al. Jurassic sedimentary facies and paleoenvironmental reconstruction of southeastern Tarim Basin, Northwestern China. J China Univ Min Technol. 2008;37: 519-25 (in Chinese).

Fang R, Li M, Wang T-G, et al. Identification and distribution of pyrene, methylpyrenes and their isomers in rock extracts and crude oils. Org Geochem. 2015;83-84:65-76.
Grafka O, Marynowski L, Simoneit BRT. Phenyl derivatives of polycyclic aromatic compounds as indicators of hydrothermal activity in the Silurian black siliceous shales of the Bardzkie Mountains, Poland. Int J Coal Geol. 2015;139(1):142-51.

Lee ML, Vassilaros DL, White CM, et al. Retention indices for programmed-temperature capillary-column gas chromatography of polycyclic aromatic hydrocarbons. J Chromatogr A. 1979; $51: 768-74$.

Li JG, Liu WH, Zheng JJ, et al. Dibenzofuran series of terrestrial source rocks and crude oils in Kuqa Depression. Acta Pet Sin. 2004;25(1):40-43, 47 (in Chinese).

Li M, Wang T, Liu J, et al. Total alkyl dibenzothiophenes content tracing the filling pathway of condensate reservoir in the Fushan depression, South China Sea. Sci China (Ser D). 2008;51:138-45.

Li M, Shi S, Wang T-G, et al. The occurrence and distribution of phenylphenanthrenes, phenylanthracenes and binaphthyls in Palaeozoic to Cenozoic shales from China. Appl Geochem. 2012a;27(12):2560-9.

Li M, Wang T, Shi S, et al. The oil maturity assessment by maturity indicators based on methylated dibenzothiophenes. Pet Sci. 2014;11(2):234-46.

Li M, Wang T-G, Lillis PG, et al. The significance of 24-norcholestanes, triaromatic steroids and dinosteroids in oils and CambrianOrdovician source rocks from the cratonic region of the Tarim Basin, NW China. Appl Geochem. 2012b;27(8):1643-54.

Li S, Pang X, Shi Q, et al. Origin of the unusually high dibenzothiophene concentrations in Lower Ordovician oils from the Tazhong Uplift, Tarim Basin, China. Pet Sci. 2011;8(4):382-91.

Liu S, Qiu M, Chen X, et al. Sedimentary setting of Mesozoic and its petroleum geologic features in western Tarim Basin. Xinjiang Pet Geol. 2006;27:10-4 (in Chinese).

Marynowski L, Czechowski F, Simoneit BRT. Phenylnaphthalenes and polyphenyls in Palaeozoic source rocks of the Holy Cross Mountains, Poland. Org Geochem. 2001;32:69-85.

Marynowski L, Rospondek MJ, zu Reckendorf RM, et al. Phenyldibenzofurans and phenyldibenzothiophenes in marine sedimentary rocks and hydrothermal petroleum. Org Geochem. 2002;33:701-14.

Marynowski L, Piet M, Janeczek J. Composition and source of polycyclic aromatic compounds in deposited dust from selected sites around the Upper Silesia, Poland. J Geol Q. 2004;48:169-80.

Moldowan JM, Sundararaman P, Schoell M. Sensitivity of biomarker properties to depositional environment and/or source input in the Lower Toarcian of SW-Germany. Org Geochem. 1986; 10(4-6):915-26.

Pang X, Tian J, Pang H, et al. Main progress and problems in research on Ordovician hydrocarbon accumulation in the Tarim Basin. Pet Sci. 2010;7(2):147-63.

Peters KE, Walters CC, Moldowan JM. The biomarker guide. 2nd ed. New York: Cambridge University Press; 2005.

Polissar PJ, Savage HM, Brodsky EE. Extractable organic material in fault zones as a tool to investigate frictional stress. Earth Planet Sci Lett. 2011;311:439-47.

Radke M, Vriend SP, Ramanampisoa LR. Alkyldibenzofurans in terrestrial rocks: influence of organic facies and maturation. Geochim Cosmochim Acta. 2000;64(2):275-86.

Radke M, Welte DH, Willsch H. Geochemical study on a well in the Western Canada Basin: relation of the aromatic distribution pattern to maturity of organic matter. Geochem Cosmochim Acta. 1982;46:1-10.

Rospondek MJ, Marynowski L, Góra M. Novel arylated polyaromatic thiophenes: phenylnaphtho[b]thiophenes and naphthylbenzo[b]thiophenes as markers of organic matter diagenesis buffered by oxidising solutions. Org Geochem. 2007;38:1729-56.

Rospondek MJ, Marynowski L, Chachaj A, et al. Novel aryl polycyclic aromatic hydrocarbons: phenylphenanthrene and 
phenylanthracene identification, occurrence and distribution in sedimentary rocks. Org Geochem. 2009;40:986-1004.

Rullkötter J, Spiro B, Nissenbaum A. Biological marker characteristics of oils and asphalts from carbonate source rocks in a rapidly subsiding graben, Dead Sea, Israel. Geochim Cosmochim Acta. 1985;49(6):1357-70.

Song D, Li M, Wang T. Geochemical studies of the Silurian oil reservoir in the Well Shun-9 prospect area, Tarim Basin, NW China. Pet Sci. 2013;10(4):432-41.

Song D, Wang T, Li H. Geochemical characteristics and origin of the crude oils and condensates from Yakela Faulted-Uplift, Tarim Basin. J Pet Sci Eng. 2015;133:602-11.

Szczerba M, Rospondek MJ. Controls on distributions of methylphenanthrenes in sedimentary rock extracts: critical evaluation of existing geochemical data from molecular modelling. Org Geochem. 2010;41:1297-311.

Voigtmann MF, Yang K, Batts BD, et al. Evidence for synthetic generation of methylphenanthrenes in sediments. Fuel. 1994;73(12):1899-1903.

Wang Z, Li K, Lambert P, et al. Identification, characterization and quantitation of pyrogenic polycylic aromatic hydrocarbons and other organic compounds in tire fire products. J Chromatogr A. 2007;1139:14-26.

Wang B, Ma H, Liu J, et al. Triassic source rock characteristics in Yakela of Shaya Uplift, Tarim Basin. Spec Oil Gas Reserv. 2009;16(2):43-6, 9 (in Chinese).

Wang T-G, He F, Li M, et al. Alkyldibenzothiophenes: molecular tracers for filling pathway in oil reservoirs. Chin Sci Bull. 2014;49(22):2399-404.
Wang T-G, He F, Wang C, et al. Oil filling history of the Ordovician oil reservoir in the major part of the Tahe Oilfield, Tarim Basin, NW China. Org Geochem. 2008;39:1637-46.

Xiao ZY, Huang GH, Lu YH, et al. Rearranged hopanes in oils from the Quele 1 Well, Tarim Basin, and the significance for oil correlation. Pet Explor Dev. 2004;31(2):35-7 (in Chinese).

Zhang C, Xiao C, Li J, et al. Depositional feature of the Jurassic fault basin in southwest Tarim depression. J Mineral Petrol. 2000;20:41-5 (in Chinese).

Zhang M, Philp P. Geochemical characterization of aromatic hydrocarbons in crude oils from the Tarim. Pet Sci. 2010;7(4):448-57.

Zhang S, Huang H. Geochemistry of Palaeozoic marine petroleum from the Tarim Basin, NW China: Part 1. Oil family classification. Org Geochem. 2005;36:1204-14.

Zhao W, Zhang S, Wang F, et al. Gas systems in the Kuche Depression of the Tarim Basin: source rock distributions, generation kinetics and gas accumulation history. Org Geochem. 2005;36(12):1583-601.

zu Reckendorf RM. Identification of phenyl-substituted polycyclic aromatic compounds in ring furnace gases using GC-MS and GC-AED. Chromatographia. 1997;45:173-82.

zu Reckendorf RM. Phenyl-substituted polycyclic aromatic compounds as intermediate products during pyrolytic reactions involving coal tars, pitches and related materials. Chromatographia. 2000;52:67-76. 